\title{
Dialectics or politics? Atheism and the return to religion
}

M uch scholarly attention has been given to the vast differences in understandings of theism throughout the history of the theological tradition. Rather less attention has been given to differences in understandings of atheism. That there are and have been such differences, however, is obvious. This may be seen in the contemporary context if we juxtapose the 'newly visible' atheisms of, for instance, Richard Dawkins and Slavoj Žižek. In previous work, I and several other scholars have drawn attention to the ways in which the existence of different forms of atheism may be explained by the fact that they are responding to and negating very different forms of theism (Hyman 2010). But there may well be more at stake in differences between atheisms than this.

ONE SIGNIFICANT DIFFERENCE that has emerged in recent years has been that between forms of atheism that are antagonistic towards religion, seeing it as something to be overcome, and those forms that in some sense have been returning to religion while remaining resolutely atheistic. How is this particular difference to be explained? That some atheists might feel moved to repudiate religion is hardly surprising; but that some atheists are actively returning to religion without in any way compromising their atheism is rather more puzzling. Perhaps the most obvious and well-known examples of such atheists would be Alain Badiou and Slavoj Žižek (and perhaps Terry Eagleton, although he has been more equivocal about his espousal of atheism than have Badiou and Žižek). As is also well known, their return to religion has to a large extent been prompted by political considerations and, in particular, a concern to revivify radical leftist politics. They see in religion (and, specifically, Christianity) an invaluable resource for the develop- ment of a thoroughly radical political thought. This return to religion on political grounds is well expressed by Eagleton when, in his inimitable style, he says:

Some of my friends and readers will be dismayed to find me wasting my time yet again on theology ... It is a paradox of our times that while it has bred various lethal brands of religious fundamentalism, it has also given birth to a current of radical theology - one which, ironically, represents one of the few surviving enclaves of materialist thought, in these politically patchy times, and which is often more revolutionary in its political implications than much secular leftist thought. It may well be a dismal sign of the times that it is to the science of God, of all things, that we must look for such subversive insights. But there is no reason to look a gift horse in the mouth. (Eagleton 2009a: vi.)

But is this all there is to be said, namely, that the only difference between Badiou and Žižek on the one hand, and Dawkins and Hitchens on the other, is that the former find political inspiration in religion while the latter do not? In other words, could it be said that while they all share a common atheistic outlook, contingent differences in their respective political outlooks explain why it is that some repudiate religion while others return to it? I want to suggest that the difference is far more deep-seated than this and, in particular, that it lies in two very different conceptions of atheism that are here being espoused. Furthermore, these two very different conceptions of atheism actually entail two very different political visions. In other words, I want to suggest that when we see that there are two qualitatively different concep- 
tions of atheism at issue, then this in itself will help to explain why the thinkers in question are led to espouse the respective political visions that they do.

In order to understand the different conceptions of atheism here at issue, it is necessary first to turn to Žižek's distinctive rendering and practice of dialectics. One would search with difficulty for an explicit discussion of this method in Žižek's works, although it is actually enacted in them time and again in many of his tantalising and innovative analyses. Indeed, Fredric Jameson has identified this as being one of the few themes that have persisted throughout Žižek's now considerable oeuvre. Of the dialectic, then, Jameson says that

[t]he old stereotype is that Hegel works according to a cut-and-dried progression from thesis, through antithesis, to synthesis. This, Žižek explains, is completely erroneous: there are no real syntheses in Hegel and the dialectical operation is to be seen in an utterly different way; a variety of examples are adduced. Still, that stupid stereotype was not altogether wrong. There is a tripartite movement in the Hegelian dialectic, and in fact, Žižek goes on, he has just illustrated it: stupid stereotype, or the 'appearance'; ingenious correction, the underlying reality or 'essence'; finally, after all, the return to the reality of the appearance, so that it was the appearance that was 'true' after all. (Jameson 2006: 7.)

So it is to the supposedly 'stupid first impression' to which we ultimately return. But, of course, this is not a simple return or a straightforward restoration. The return to the first impression is one that is cognisant of the dialectical movement that has made this return possible. The 'first impression' that is restored is not the same as the first impression that was left behind.

For Jameson, it is this very movement - this restoration that is at the same time a displacement - that constitutes the perversity of the dialectic. As he continues:

the dialectic is just that inveterate, infuriating perversity whereby a commonsense empiricist view of reality is repudiated and undermined. But it is undermined together with its own accompanying interpretations of that reality, which look so much more astute and ingenious than the commonsense empiricist reality itself, until we understand that the interpretations are themselves also part of precisely that 'first impression'. (Jameson 2006: 7.)

The radical implication of this, as Jameson points out, is the impossibility of philosophy as such, and the consequent displacement of philosophy by theory. This is because philosophy is predicated on the notion of a foundational subject that abstracts itself from the object under consideration in order to provide a complete and systematic account of the object ('reality') as a whole. Dialectics questions the very possibility of this abstract stance of subjective observation. The subject itself is always 'caught up' in and is a part of that which is being observed. As Žižek puts it:
the subject's gaze is always-already inscribed into the perceived object itself ... [which] means that the reality I see is never 'whole' - not because a large part of it eludes me, but because it contains a stain, a blind spot, which indicates my inclusion in it (Žižek 2006: 17).

In light of this, therefore, one can see why a return to the initial impression - by means of this detour of dialectical negation - is not a simple return or a straightforward restoration. The paradox (or perversity) here is that the return to the origin is made possible precisely by this recognition (attained by means of the dialectical movement) that the origin in itself is impossible.

But how does this analysis help to clarify the nature of the differences between the two types of atheism from which I began? I want to suggest that it provides us with one way of understanding the transition from theism to atheism (and beyond). On this reading, the 'stupid first impression' is that God exists. In very broad terms, this would encapsulate the worldview of pre-modern Christianity. In this rendering of theism, there is a transcendent God who creates and sustains the world. We, as creatures, are 'effects' of that God and, as such, are ultimately answerable to and utterly dependent on him. Truth is 'given' or 'revealed' as a divine gift, to be gratefully received by creaturely recipients. This world-view is for the most part an enclosed system, such that it can scarcely be contested. There were undoubtedly heresies and the persecution of heretics, but such acts of dissent took place within a system that itself remained uncontested. As numerous scholars have noted, 'atheism' is virtually unknown in medieval Christendom, and doesn't begin to rear its head until the early seven- 
teenth century. ${ }^{1}$ The possibility of dissent has not yet been created because the epistemological autonomy of the subject has yet to be asserted.

In time, however, this 'stupid first impression', mired in ignorance and superstition, gives way to its 'ingenious correction', the exposure of its underlying reality or essence. This is atheism, the realisation that we are 'really' on our own, that God was always a fiction, a projection of humanity, that revelation was, after all, merely a myth. The story of the transition from theism to atheism is often portrayed as being a long and complicated one, constituted by a whole series of contingent shifts. In a way, of course, this was undoubtedly so, but there is another sense in which the transition was remarkably simple and abrupt. It can be traced, pre-eminently, to Descartes's self-reflexive establishment of foundational subjectivity. This revolutionary epistemological shift was effected by the abstraction of the human subject from the reality of which it was formerly an intrinsic part. This was a direct inversion of the previously prevailing epistemology. Hitherto, the subject had been an effect of, a creation of, that wider reality, whereas now, the subject becomes the only certain reality which in turn has to found, justify, substantiate and in a certain sense 'create' a reality, the existence of which is otherwise radically uncertain. Initially, of course, Descartes must invoke God in order to secure the existence of the external world. But this God now has to be founded, in turn, on the rationality of the human subject. Over the ensuing centuries, this subjective 'founding' of God is exposed as being what it is - a groundless projection. Ultimately, therefore, Descartes's atheistic methodology is shown necessarily to give rise to atheistic conclusions. The subject is the only true reality and all conceptions of God are merely subjective projections. This is the ingenious correction', the exposure of the real 'essence' underlying the ignorant 'appearance' of the pre-modern world.

But before long, this 'ingenious correction' is itself put into question. In turn, the 'real essence' it has exposed comes itself to be seen as yet another fictional appearance. In particular, the abstract subject, detached from its context, comes to be seen as a bizarre and peculiar projection, which ultimately shows it-

The classic statement of this may be found in Febvre 1982, originally published in French in 1942, in which he claimed that atheism was 'unthinkable' in medieval Christendom. Numerous subsequent scholars have made similar (if sometimes more understated) claims. self to be unsustainable. This realisation has been well expressed by John Milbank when he says that: 'we should ask why the West gave birth to anything so fantastically peculiar and unlikely' as the invention of

a wholly artificial human being who has never really existed ... This is the pure individual, thought of in abstraction from his or her gender, birth, associations, beliefs and also, crucially, in equal abstraction from the religious or philosophical beliefs of the observer of this individual as to whether he is a creature made by God, or only material, or naturally evolved and so forth. Such an individual is not only asocial, he is also apsychological; his soul is in every way unspecified. (Milbank 2004: 213.)

Not only is this abstract subject increasingly seen as being philosophically 'peculiar and unlikely' in the way Milbank describes, but it is also seen as laying the foundations of a radical immanence, which has far-reaching implications, philosophically, socially and culturally.

These implications are manifested in manifold ways. In general cultural terms, the philosopher Charles Taylor has illuminated what is at issue here when he says that

[t]here is a generalized sense in our culture that with the eclipse of the transcendent, something may have been lost. I put it in the optative mood, because people react very differently to this ... But wherever people stand on this issue, everyone understands, or feels they understand what is being talked about here. (Taylor 2007: 307.)

More specifically, Taylor identifies three forms which this 'malaise of immanence' may take: '(1) the sense of the fragility of meaning, the search for an overarching significance; (2) the felt flatness of our attempts to solemnize the crucial moments of passage in our lives; and (3) the utter flatness, emptiness of the ordinary' (Taylor 2007: 309). Furthermore, there is an increasing sense that, even on its own terms, the immanence, rationality and objectivity of modern subjectivity are illusory. The development of Freudian and post-Freudian psychoanalysis has, of course, had a great deal to do with this. When Freud began his ground-breaking investigations, he did so from within rather than from without the framework of modern subjective rationality. But his work ultimate- 
ly resulted in a subversion of that framework from within. The subject's immanence was shown to be saturated by an uncontrollable 'excess', its rationality was seen to be underpinned by an irrationality that is in a sense more foundational, while its objectivity was shown to be, in many ways, a secondary construction.

These are all enormously complex processes and, in this context, we can do little more than gesture, vaguely, towards them. But in philosophical, cultural and psychoanalytical terms, what we see is that the 'ingenious correction' or 'sophisticated interpretation' itself begins to crumble from within. As it does so, a suspicion emerges that the initial 'stupid impression' was perhaps in a sense true after all. It is possibly in this context that the much touted contemporary 'return of religion' should be understood. At the very least, it is the context within which Žižek's return to religion should be understood. As we have seen, the return to the 'stupid first impression' is not a simple or straightforward restoration of it. The return has been made possible precisely through the dialectical detour through the 'ingenious correction', in this case, modern atheism. This antithesis is both cancelled or annulled and also taken up or carried forward into the return to the initial thesis, the 'stupid first impression. The precise way in which the atheistic antithesis is both annulled and carried forward is, however, a matter of some contention, and much rests on whether it is the annulment or the perpetuation that is prioritised. Indeed, we may well say that this is the very thing that is at stake in the dispute between Žižek and Milbank (see Žižek \& Milbank 2009). I should suggest that their respective returns to religion may both be understood in terms of this dialectical detour via the antithesis of modern atheism. ${ }^{2}$ For both of them, their return to religion can only be properly understood in light of this detour, but whereas, for Milbank, the return entails an annulment of atheism, for Žižek, it entails a perpetuation of it. And yet, this perpetuation is sustained precisely on the basis of its annulment; the atheism that is perpetuated is not the same as the atheism that has been left behind. The logic here is rather like the one that pertains to Žižek's parallel perpetuation of

2 Of course, Milbank has never explicitly endorsed dialectics in the way that Žižek has, and, indeed, he has often been directly critical of it. On the other hand, there are places where Milbank himself seems to understand his relationship to secular modernity in precisely dialectical terms. For further discussion of this, see Hyman 2009. materialism. The materialism to which Žižek is committed is not the inert, static, immanent materialism of secular modernity. Rather, materialism itself contains an excess - a transcendence - that exceeds itself. This excess or transcendence is not dualistically other than, or set over and against the material, but rather is an intrinsic facet of the material as such.

The application of this logic to the question of atheism is enacted directly by Žižek himself, when he says that:

I don't think one can translate theology into secular humanism. Not because of any secret, obscure reason but because there must be a moment of thinking that it is not we who are acting, but a higher force that is acting through us. This element has to be maintained. (Žižek 2010: 179-80.)

In other words, there is an excess to human subjectivity that is beyond its control, a transcendent excess that immanent humanistic atheism cannot countenance. The latter wants to maintain a conception of subjectivity understood unequivocally in nominative terms, whereas Žižek wants to return to the theological understanding of subjectivity as existing fundamentally in an accusative tense; to retain the sense of a 'force' or 'power' by which we are addressed and which acts through us. At the same time, this 'force' or 'power' does not constitute some kind of occult, hidden, transcendent realm. Rather, it is a necessary aspect of subjectivity as such. He goes on to say that at the Crucifixion, the Roman soldiers

thought they had destroyed everything in Christ, but that little bit of alien residue remained and started to organize itself into the community of believers. That is a crucial point. Again, what I'm saying here cannot be reduced to simplistic humanism. I think this is the legacy of Christianity - this legacy of God not as a big Other or guarantee but God as the ultimate ethical agency who puts the burden on us to organize ourselves. (Žižek 2010: 180.)

In other words, the repudiation of God as a big Other is, in effect, a perpetuation of atheism. But this is not an atheism of absolute immanence - the atheism of secular modernity. Rather, it is an atheism that acknowledges the necessity of God as a 'force' or 'power' that is an effect of immanence itself. But although it is an effect of immanence, it is not simply 'produced' or 


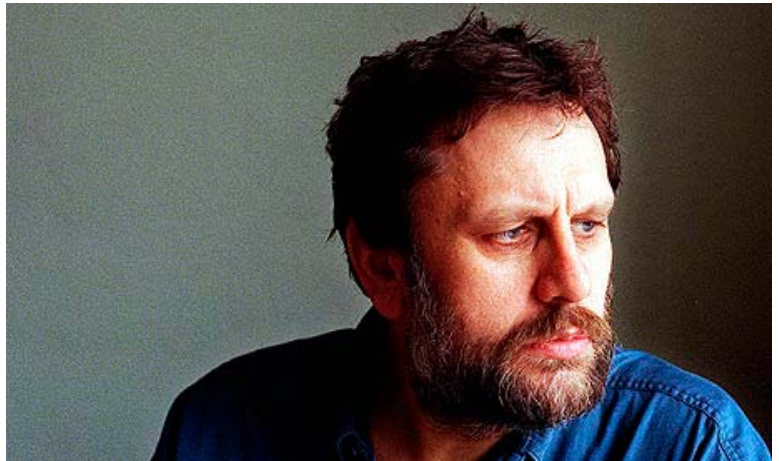

Slavoj Žižek. Photo by Mykel Nicolaou/Rex.

'projected' by humanity. As an 'excess', it is something that exceeds our grasp or control.

In light of all this, we can see that the difference between Žižek and Dawkins is not simply a difference between one who espouses a revolutionary Leftist politics and one who does not. Neither is it a difference between one who returns to religion as a political resource and one who repudiates it. On the contrary, quite apart from any political considerations, we can see here that there are actually two very different versions of atheism being espoused. In the terms of the 'old stereotype' of Hegelian dialectics, we may say that Dawkins's atheism is an embodiment of the antithesis in relation to religion, whereas Žižek's atheism is an embodiment of the synthesis (while acknowledging that Žižek has questioned the reality of any such syntheses in Hegel's work). If this is so, we can see that Žižek's atheism is as different from Dawkins's atheism as the latter is from theism itself. For Žižek, as for Hegel, a simple movement from thesis to antithesis will always be inadequate and incomplete. What is needed is a return to the 'stupid first impression', albeit in such a way that both annuls and perpetuates the antithesis. The latter is annulled in so far as there is a repudiation of absolute immanence, of the final truth of humanistic atheism, and a return to Christianity itself. At the same time, the atheistic antithesis is perpetuated in so far as this movement is one that remains resolutely atheistic and materialist.

But to return to the question with which we began, does this mean that the differences between Žižek's atheism and Dawkins's atheism can be explained without any reference to the domain of the political? Our initial impression - that Žižek's return to religion and Dawkins's repudiation of religion were alike motivated by political concerns - would seem not to be sustainable. For on the basis of what has been said so far, it would appear that the difference can be explained entirely in terms of the dialectic, without any reference to the political. But I now want to suggest that our initial impression was perhaps not so misleading after all. For at each stage of the tripartite structure of the dialectic, there is a corresponding political implication. Each stage entails a particular political configuration and, if this is so, it would suggest that the difference between these two kinds of atheisms are intimately bound up with political differences after all, albeit not in any straightforward, foundational way.

Let us return, then, to the thesis of pre-modern theism. Political thinking from the time of Augustine until well into the medieval period was predicated on the assumption that the worldly political order should both participate in and mirror the divine heavenly order. Just as there is a hierarchy between the heavenly and earthly cities, so too there is a corresponding hierarchy within the earthly city itself. Just as creatures owe gratitude and obedience to God, so too subjects owe gratitude and obedience to their earthly rulers. Just as God is responsible for and seeks justice for all his creatures, so too earthly rulers are responsible for and seek justice for all their subjects. Just as divine love and justice are all-embracing, so too charity and justice are thought properly to saturate every aspect of worldly life. There are no compartmentalised exceptions. The spheres of commerce and business are as much to be conducted in a spirit of love, charity and justice as is any other sphere of life. ${ }^{3}$ At the same time, there is a recognition that the earthly city cannot be equated with the heavenly city. The earthly city is fallen and corrupt and it would be dangerous to pretend otherwise. As Charles Taylor points out, this sensibility can be traced back to $\mathrm{Au}$ gustine, who had a strong sense of

the gap between the city of God and the earthly city, so that the attempt by the magisterium, seconded by state power, to bring society more in line with the heavenly city would have certainly appeared extremely hazardous to him, at the least. Of course, reforming Popes accepted that the fullness of justice, which for Augustine must include giving to God his due, cannot be expected in this world. Sinners will abound until the end. But a regime can be envisaged in which people are subordinated to rule which

3 The classic exposition of this analysis was Tawney 1926. 
models itself on full justice. If kingly power really follows the injunctions of those speaking with the authority of God's will (the hierarchy of the Church), then an order can be established in which those truly good will rule, and the bad will be forced to conform. (Taylor 2007: 243.)

Pre-modern theism therefore entails a certain kind of political vision, which has justice at its heart, and which is hierarchically ordered towards its transcendent divine telos.

We have seen that this hierarchical transcendent ontology came to be replaced by one wherein there was a single plane of immanence, on which the sole source of authority was that of the human subject. In this new ontological setting, the old political project became incoherent and unsustainable. Instead, a new political order had to be founded, which was consistent with an ontology of thoroughgoing immanence and that was predicated on the foundationalism of the abstract human subject. This work was undertaken by Locke and Hobbes, among others, and would ultimately culminate in the various configurations of western liberal democracy. As with the transition from Descartes's epistemological revolution to late modern secular humanism, this was in one sense a long and complex process and in another sense a startlingly sudden innovation. While some of the language and appearance of transcendence was preserved, particularly in relation to the perpetuation of monarchy, this now plays an utterly different role. In an ontology that is constituted by a plane of immanence, within which human subjects have become foundational, there is no longer any question of the political configuration 'participating' in or 'mirroring' the heavenly city. Human subjects themselves are pre-eminent; the political domain itself emerges as a secondary supplement in order to mitigate the severity of potential conflict between these sovereign subjects pursuing their own (individual) goods. It is this disciplinary and mediating function that is fulfilled by the remnants of transcendence.

Michael Hardt and Antonio Negri have spoken of this as a 'weak transcendence'. They have suggested that in early modernity, the multitude could not be understood as being in 'a direct, immediate relation with divinity and nature, as the ethical producer of life and the world' (as was the case with Spinoza, one of Hardt and Negri's philosophical heroes), as this would have given rise to a 'subversive delirium'. Instead, a mediation was needed, a 'sort of weak transcendence', whereby the multitude would 'yield to a preconsti- tuted order' (Hardt \& Negri 2000: 78-9). This 'weak transcendence' was installed by Descartes and then taken to its apotheosis by Kant. The aim was to

eliminate the medieval form of transcendence, which only inhibits production and consumption, while maintaining transcendence's effects of domination in a form adequate to the modes of association and production of the new humanity. The center of the problem of modernity was thus demonstrated in political philosophy, and here was where the new form of mediation found its most adequate response to the revolutionary forms of immanence; a transcendent political apparatus. (Hardt \& Negri 2000: 83.)

In particular, Hobbes's conception of an absolute sovereign rule plays a major part in the modern construction of this apparatus. Democracy consequently emerges as a supposedly non-coercive regulation of the irreducible differences between sovereign subjects. The free market is the economic plane on which sovereign subjects pursue their own material interests. These structures are thought to be 'value free' or ideologically 'neutral'. In the absence of transcendent norms and universal conceptions of 'good' or 'justice' around which a consensus might emerge, such values now become 'subjective', matters for the 'individual. The public political structures and economic mechanisms, meanwhile, become neutrally bureaucratic or procedural. The old notion that the pursuit of commerce and business ought to be saturated with charity, love and justice, is now seen to be a naive illusion. This reading is the 'ingenious correction', a clear-sighted view of the world as it 'really' is. Just as God has been unmasked as a projection, so too a political order based on transcendent norms is unmasked as a naive illusion, a fictional 'appearance.' Secular democracy and free market capitalism constitute the 'ingenious correction'. It is the sophisticated, clear-sighted, realistic exposure of political life as it 'really' is, purged of all sentimental illusion.

As such, it is also the political accomplice of modern atheism or secular humanism. Both are aspects of the same antithesis, the reaction against the thesis of pre-modern theism and its accompanying politico-theological vision. If this is so, then it is entirely to be expected that Richard Dawkins, Christopher Hitchens and others of the 'New Atheists' would be enthusiastic proponents of liberal democracy and free market capitalism. Indeed, the connection between late capitalism and 'antithetical' atheism has 
been explicitly made by Terry Eagleton, when he comments that

[t]he advanced capitalist system is inherently atheistic. It is godless in its actual material practices, and in the values and beliefs implicit in them, whatever some of its apologists may piously aver. As such, it is atheistic in all the wrong ways, whereas Marx and Nietzsche are atheistic in what are by and large the right kinds of ways. A society of packaged fulfilment, administered desire, managerialized politics, and consumerist economics is unlikely to cut to the kind of depth where theological questions can even be properly raised, just as it rules out political and moral questions of a certain profundity. (Eagleton 2009b: 39.)

For Eagleton, therefore, what I am calling a 'reactive' or 'antithetical' atheism would appear to be both indissolubly wedded to the liberal democratic-capitalist political configuration and also deaf to a more profound form of political thought that would put that into question.

Indeed, this dissatisfaction is one that has become increasingly widespread. As democracy has itself become increasingly homogenized and increasingly inimical to genuine freedom, and as capitalism has become more advanced and less restrained, the injustices and enslavement that it entails have become increasingly evident. The resulting protests have been articulated not only by philosophers, intellectuals and academics, but also by numerous popular movements around the world (politicians, meanwhile, have been notably silent). The 'ingenious correction',

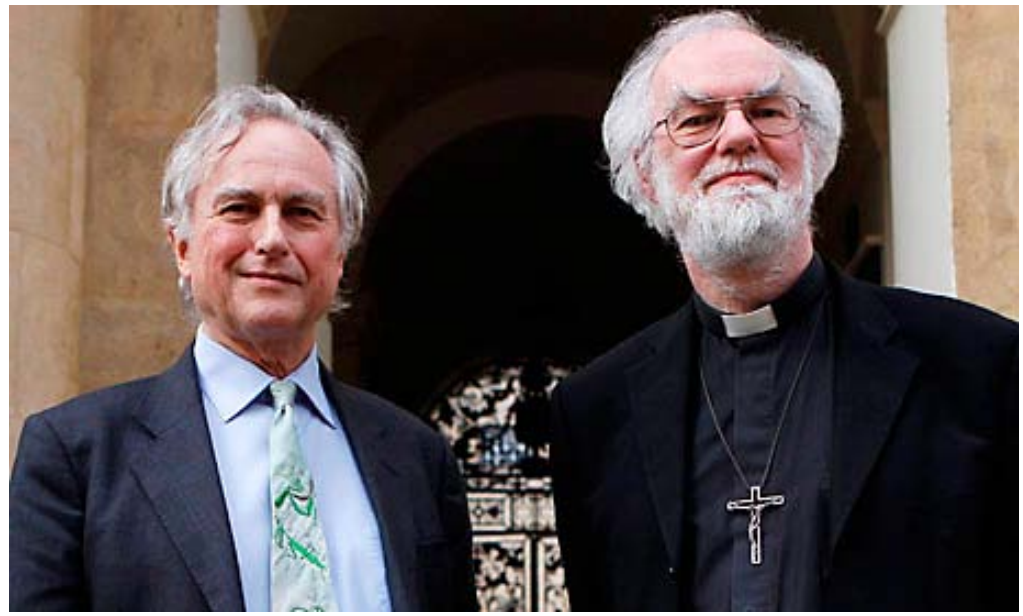

Richard Dawkins and Rowan Williams pose for a photograph before their debate. Photo by Andrew Winning/Reuters. the 'sophisticated realism' comes to be exposed as yet another fiction, and a fiction that promotes certain power interests that are ultimately damaging to the common good. Political structures that were once thought to be ideologically 'neutral' or 'empty' are exposed as embodying a still deeper ideology in turn. It is an ideology of monadic atomism, wilful assertion, relentless acquisition and shallow materialism. In this context, it is little wonder that the 'stupid first impression', the 'naive fiction' of a political order committed to a justice derived from a common notion of what is good for all, comes to be seen as increasingly attractive. Perhaps this 'stupid first impression' was in a sense right after all.

Rowan Williams has given expression to this when he says that liberal capitalism conceives of meaningful action as successful assertion. He says that

[t]o the extent that popular liberal and pluralist thought assumes with blithe unawareness a basic model of meaningful action in terms of assertion, it assumes a final social unintelligibility, an ultimate inability to make sense of each other's actions (which involves understanding so as to query and reexpress) - and thus raises the spectre of the purest fascism, an uncriticizable exercise of social power in the name of a supposed corporate assertion (Williams 2005: 2).

He contrasts this with an account of intelligible action whereby 'we claim to have offered a representation of something prior in such a way as to introduce that prior and shaping reality into a continuing narrative of uncovering through response and question.' This entails the 'unfolding through representation of a content not exhausted by my action and determination alone. (Williams 2005: 1-2.) He suggests that this constitutes common ground between $\mathrm{Au}-$ gustine, Hegel and Marx.

This would certainly seem to illuminate Eagleton's comment that Marx's atheism is the 'right' kind of atheism, that is to say (in terms of my analysis), it is an atheism that has moved through and beyond antithetical atheism and its accompanying atomistic political configuration, back to a politics that restores an account of meaningful action of the kind described by Williams. Again, this 'return' to the thesis is 
not a simple restoration. The fact that this kind of political restoration has been made possible by the dialectical detour through liberal democracy means the restored will at the same time be transformed. Williams has elsewhere suggested that the dialectical detour through secular modernity was in a sense necessary. He has pointed out that pre-modern political configurations harboured all kinds of violent and oppressive features which cannot and should not be restored; the dialectical detour through the political Enlightenment was necessary in precisely this respect. ${ }^{4}$ As we have observed, the negation of the antithesis entails that it be not only annulled but also perpetuated.

Insofar as Williams is right to identify this common ground between Augustine, Hegel and Marx, it would also illuminate why so many thinkers have been returning to one or other of these thinkers in recent political thought. Žižek, perhaps unusually, returns to all three. But there can be little doubt that his return to Christianity has been motivated by political considerations. In particular, he has emphasised the critical link between Christianity and 'progressive' politics, and, in so doing, he has emphasised the way in which the political task now is to move beyond both thesis and antithesis. In a lengthy passage worth quoting in full, he says:

The ideal is that of neither blind liberal individuals collaborating with one another nor the old organic conservative community. It is a community along the lines of the original Christian community: a community of outcasts. We need this today, this idea of an egalitarian community of believers that is neither the traditional heretical community nor the liberal multiplicity. This is why I and so many other leftist philosophers, such as Alain Badiou and others, are so interested in rereading, rehabilitating, and reappropriating the legacy of Paul. It is not just a matter of private religious convictions. I claim that if we lose this key moment - the moment of realizing the Holy Spirit as a community of believers - we will live in a very sad society, where the only choice will be between vulgar egoist liberalism or the fundamentalism that

In Williams 2008, he has observed that slave societies and assumptions about innate racial superiority 'have persistently infected even Abrahamic communities, which is perhaps why the Enlightenment was a necessary wake-up call to religion. counterattacks it. This is why I - precisely as a radical leftist - think that Christianity is far too precious a thing to leave to Christian fundamentalists. We should fight for it. Our message should not be, 'You can have it,' but 'No, it's ours. You are kidnapping it.' (Žižek 2010: 181.)

This revealing passage gives a very clear sense that Žižek's return to Christianity is motivated primarily by political concerns. As he emphasises, it is not a matter of private religious convictions; for specifically political reasons, the return to Christianity appears to be unavoidable. It would seem that our initial impression, from which we began our discussion, is, in a sense true, after all.

It might therefore be said that the path on which we have travelled is itself an instance of that of which it speaks. We began with the 'stupid first impression' that the difference between the respective atheisms of Žižek and Dawkins was simply that the former found radical political inspiration in Christianity while the latter did not. But this initial impression was corrected by the 'ingenious interpretation' - that there are two qualitatively different conceptions of atheisms at work here; two different conceptions that arise not primarily from political differences at all, but from the operation of dialectics. In turn, however, we also saw that the two atheisms thus produced were indissolubly linked to two respective and qualitatively different political configurations. One impelled a return to Christianity while the other required a repudiation of it. Our 'stupid first impression' was perhaps close to the truth after all. But at the same time, that first impression could only properly be understood in light of the 'ingenious correction.' It is only by actually passing through this dialectical process that we can come to a full appreciation of the differences at stake between the respective atheisms of the 'New Atheists' and 'New Leftists' in Europe today.

Gavin Hyman is Lecturer in the Department of Politics, Philosophy and Religion at the University of Lancaster, UK. He completed his doctoral dissertation at Peterhouse, Cambridge, and has taught at Lancaster for the past twelve years. He is author of The Predicament of Postmodern Theology (2001) and $A$ Short History of Atheism (2010), and editor of New Directions in Philosophical Theology (2004).

Email: g.hyman(at)lancaster.ac.uk.

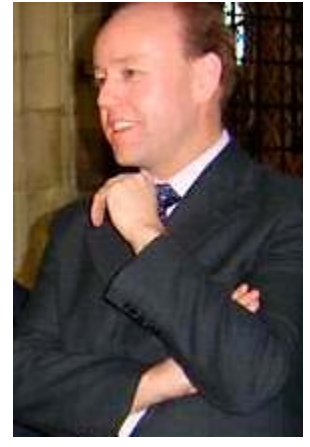

4 


\section{Bibliography}

Eagleton, Terry 2009a. Trouble with Strangers: A Study of Ethics. Chichester: Wiley-Blackwell.

-2009b. Reason, Faith, and Revolution: Reflections on the God Debate. New Haven: Yale University Press.

Febvre, Lucien 1982. The Problem of Unbelief in the Sixteenth Century: The Religion of Rabelais. Trans. Beatrice Gottlieb. Cambridge, Mass.: Harvard University Press.

Hardt, Michael \& Antonio Negri 2000. Empire. Cambridge, Mass.: Harvard University Press.

Hyman, Gavin 2009. 'Postmodern Theology and Modern Liberalism: Reconsidering the Relationship.' Theology Today 65: 462-74.

-2010. A Short History of Atheism. London: I. B. Tauris.

Jameson, Fredric 2006. 'First Impressions'. London Review of Books 28 (17): 7-8.

Milbank, John 2004. 'The Gift of Ruling: Secularization and Political Authority'. New Blackfriars 85: 212-38.

Taylor, Charles 2007. A Secular Age. Harvard, MA: The Belknap Press of Harvard University Press.

Tawney, R. H. 1926. Religion and the Rise of Capitalism: A Historical Study. London: John Murray.

Williams, Rowan 2005. 'Introducing the Debate: Theology and the Political.' In: Creston Davis, John Milbank \& Slavoj Žižek (eds), Theology and the Political: The New Debate. 1-3. Durham, NC: Duke University Press.

-2008. 'Civil and Religious Law in England: A Religious Perspective.' Lecture delivered at the Royal Courts of Justice, 7 th February 2008 (accessed on 2.3.2012). http://www.archbishopofcanterbury.org/1575.

Žižek, Slavoj 2006. The Parallax View. Cambridge, Mass.: MIT Press.

-2010. 'A Meditation on Michelangelo's Christ on the Cross.' In: John Milbank, Slavoj Žižek \& Creston Davis (eds), Paul's New Moment: Continental Philosophy and the Future of Christian Theology. 169-81. Grand Rapids: Brazos Press.

Žižek, Slavoj \& John Milbank 2009. The Monstrosity of Christ: Paradox or Dialectic? Cambridge, Mass.: The MIT Press. 